\title{
PERJANJIAN KAWIN YANG DIBUAT SETELAH PERKAWINAN TERHADAP PIHAK KETIGA (PASCA PUTUSAN MAHKMAH KONSTITUSI NOMOR 69/PUU-XIII/2015)
}

\author{
Oleh \\ Ahmad Royani \\ Dosen Fakultas Hukum Universitas Islam Lamongan
}

\begin{abstract}
Abstrak
Perjanjian kawin adalah suatu perjanjian yang dibuat atas permintaan dari sepasang calon suami istri, dimana mereka berdua telah setuju dan sepakat untuk membuat pemisahan harta mereka masing-masing. Yang mana perjanjian kawin yang dibuat oleh calon suami istri adalah untuk menyimpang peraturan tentang bergabungnya harta kekayaan dalam perkawinan yang diatur dalam Undang-Undang Nomor 1 Tahun 1974 tentang Perkawinan. Lahirnya Putusan Mahkamah Konstitusi Nomor 69/PUU-XIII/2015 yang membawa perspektif baru tentang kesepakatan perkawinan dimana perjanjian kawin dapat dilakukan selama dalam ikatan perkawinan. Yang memiliki dampak positif dan juga berdampak negatif terhadap pihak ketiga yang terkait.
\end{abstract}

Kata Kunci : Perjanjian kawin, Pihak ketiga.

\section{PENDAHULUAN}

\section{A. Latar Belakang}

Perjanjian kawin atau yang pada umumnya disebut perjanjian pra nikah adalah perjanjian kawin yang dibuat oleh calon suami dan istri, yang dibuat secara otentik di hadapan notaris atau yang menyatakan bahwa mereka telah saling setuju dan mufakat untuk membuat pemisahan harta benda kekayaan mereka masing-masing. Perkawinan menurut pasal 1 UndangUndang Nomor 1 Tahun 1974 tentang Perkawinan disebutkan perkawinan sebagai ikatan lahir bathin antara seorang pria dan wanita sebagai suami istri dengan tujuan membentuk keluarga atau rumah tangga yang bahagia dan kekal berdasarkan Ketuhanan Yang Maha Esa.

Perjanjian kawin tersebut adalah perjanjian yang dikenal dalam Kitab Undang-Undang Hukum Perdata maupun Undang-Undang Nomor 1 Tahun 1974 tentang Perkawinan. Dalam ketentuan Pasal 139 KUHPerdata dinyatakan bahwa :
"Dengan mengadakan perjanjian perkawinan, kedua calon suami istri adalah berhak menyiapkan beberapa penyimpangan dari peraturan undang-undang sekitar persatuan harta kekayaan, asal perjanjian itu tidak menyalahi tata susila yang baik atau tata tertib umum dan asal diindahkan pula segala ketentuan"

Yang intinya perjanjian kawin adalah perjanjian mengenahi harta benda suami istri selama perkawinan mereka, yang menyimpang dari azas atau pola yang ditetapkan oleh undang-undang. Demikian pula dengan hutang-hutang dari masingmasing pihak tersebut akan tetap menjadi tanggungjawab dari pihak yang memiliki hutang tersebut. Selanjutnya dalam pasal 147 juncto 149 KUHPerdata dinyatakan bahwa perjanjian kawin tersebut harus dibuat dengan akta Notaris sebelum 
dilangsungkannya perkawinan, perjanjian mana mulai berlaku sejak saat perkawinan dilangsungkan dan tidak boleh ditarik kembali atau diubah dengan cara bagaimanapun selama berlangsungnya perkawinan.

$\begin{array}{lrr}\text { Diatur } & \text { dalam Undang-Undang } \\ \text { Nomor 1 Tahun } 1974 & \text { tentang } \\ \text { Perkawinan Pasal 29, yang } \\ \text { menentukan bahwa : }\end{array}$

1. Pada waktu atau sebelum perkawinan dilangsungkan, kedua pihak atas persetujuan bersama dapat mengadakan perjanjian tertulis yang disahkan oleh pegawai pencatat perkawinan, setelah mana isinya berlaku juga terhadap pihak ketiga yang tersangkut.

2. Perjanjian tersebut tidak dapat disahkan bilamana melanggar batas-batas hukum, agama, dan kesusilaan.

3. Perjanjian tersebut berlaku sejak perkawinan dilangsungkan.

4. Selama perkawinan berlangsung perjanjian tersebut tidak dapat dirubah, kecuali bila dari kedua belah pihak ada persetujuan untuk merubah dan perubahan tidak merugikan pihak ketiga.

Dari ketentuan yang terdapat dalam Pasal 29 Undang-Undang Perkawinan tersebut dengan jelas telah diatur bahwa perjanjian kawin tersebut harus dilaksanakan pada waktu atau sebelum perkawinan dilangsungkan, hal serupa juga diatur didalam Pasal 147 KUHPerdata yang menyebutkan bahwa perjanjian kawin haruslah dibuat dengan akta Notaris dan harus dibuat sebelum perkawinan dilangsungkan.

Ditengah dinamika perkembangan masyarakat dan perkembangan di berbagai sektor kehidupan, kebutuhan untuk memisahkan harta benda kekayaan dalam perkawinan menjadi suatu hal yang biasa dan berkembang sejalan dengan pembaruan hukum di berbagai bidang.

Salah satunya adalah Putusan Mahkamah Konstitusi Nomor 69/PUU-XIII/2015 yang mengubah beberapa ketentuan yang sebelumnya diatur dalam Pasal 29 Undang-Undang Nomor 1 Tahun 1974 tentang Perkawinan antara lain bahwa perjanjian kawin dapat dibuat sebelum, pada saat dalam selama dalam ikatan perkawinan. Ketentuan tersebut mengesampingkan ketentuan yang ada sebelumnya bahwa perjanjian kawin hanya dapat dibuat sebelum dan pada saat perkawinan dilangsungkan.

Ditegaskan pula dalam Putusan Mahkamah Konstitusi tersebut bahwa perjanjian kawin dibuat secara tertulis yang disahkan oleh pegawai pencatat perkawinan atau Notaris. Ketentuan ini mempertegas siapa saja yang berwenang mengesahkan perjanjian kawin tersebut.

Dapat dilihat pula bahwa perjanjian kawin tersebut berlaku sejak perkawinan dilangsungkan apabila perjanjian kawin dibuat selama perkawinan atau sejak waktu yang ditentukan dalam perjanjian apabila dibuat selam dalam ikatan perkawinan. Dan yang terakhir mengenai Putusan Mahkamah Konstitusi ini adalah adanya ketentuan bahwa perjanjian kawin dapat diubah atau dicabut berdasarkan kesepakatan kedua belah pihak, selama hal tersebut tidak merugikan pihak ketiga. Sebelum adanya Putusan Mahkamah Konstitusi ini perjanjian kawin hanya dapat diubah saja tetapi tidak dapat dicabut.

Hadirnya Putusan Mahkamah Konstitusi tersebut satu sisi membawa dampak positif bagi pihak-pihak yang pada saat perkawinan dilangsungkan tidak membuat perjanjian perkawinan dan kemudian baru menyadari perlunya perjanjian kawin dalam 
perkawinan mereka. Disisi lain berdampak negatif bagi pihak ketiga yang dirugikan akibat perjanjian kawin yang dapat dibuat setelah perkawinan atau dalam ikatan perkawinan berlangsung. Dalam hal ini perjanjian kredit, yang mana perjanjian kredit dibuat terlebih dahulu sebelum dibuatnya perjanjian kawin yang dibuat setelah perkawinan akan cenderung merugikan pihak kreditur terkait bagaimana cara pelunasan hutang yang telah ada ataupun bagaimana perlindungan hukum bagi kreditur akibat adanya perjanjian kawin yang dibuat setelah perkawinan tersebut apabila terjadi wanprestasi.

Berdasarkan Putusan Mahkamah Konstitusi tersebut diatas penulis tertarik mengalisa bagaimana kedudukan hukum perjanjian kawin yang dibuat setelah perkawinan terhadap pihak ketiga.

\section{B. Tujuan Penelitian}

Dalam menentukan tujuan penelitian yang hendak dicapai, maka berdasarkan latar belakang masalah, perumusan masalah, maka tujuan dari penelitian adalah sebagai berikut :

a. Untuk mengetahui kedudukan hukum perjanjian kawin yang dibuat setelah perkawinan pasca putusan Mahkamah Konstitusi nomor 69/PUU-XIII/2015.

b. Untuk mengetahui akibat hukum perjanjian kawin yang dibuat setelah perkawinan terhadap pihak ketiga pacsa Putusan Mahkamah Kostitusi nomor 69/PUU-XIII/2015.

\section{HASIL PENELITIAN DAN PEMBAHASAN}

\section{A. Kedudukan Hukum Perjanjian Kawin Yang Dibuat Setelah Perkawinan}

Perjanjian Kawin atau perjanjian pra nikah adalah suatu perjanjian yang dibuat oleh suami istri sebelum atau pada saat pernikahan dilangsungkan untuk mengatur akibat-akibat perkawinan terhadap harta kekayaan mereka. Pada umumnya perjanjian kawin ini dibuat :

1. Bilamana terdapat sejumlah harta kekayaan yang lebih besar pada salah satu pihak daripada pihak yang lain.

2. Kedua belah pihak masingmasing membawa masukan (aanbrengst) yang cukup besar.

3. Masing-masing mempunyai usaha sendiri-sendiri, sehingga andaikan salah satu jatuh "failiet", yang lain tidak tersangkut.

4. Atas hutang-hutang yang mereka buat sebelum kawin, masingmasing akan bertanggunggugat sendiri-sendiri.

Maksud pembuatan perjanjian kawin ini adalah untuk mengadakan penyimpangan terhadap ketentuanketentuan tentang harta kekayaan bersama seperti yang ditetapkan dalam Pasal 119 Kitab Undang-Undang Hukum Perdata yang menyatakan :

"Mulai saat perkawinan dilangsungkan, demi hukum berlakunya persatuan bulat antara harta kekayaan suami dan istri, sekedar mengenai itu dengan perjanjian kawin tidak diadakan ketentuan lain. Persatuan itu sepanjang perkawinan tak boleh ditiadakan atau diubah dengan sesuatu persetujuan antara suami dan istri”.

Para pihak bebas untuk menentukan bwntuk hukum yang dikehendakinya atas harta kekayaan yang menjadi obyeknya. Mereka dapat saja menentukan, bahwa di dalam perkawinan mereka sama sekali tidak akan terdapat kebersamaan harta 
kekayaan atau kebersamaan harta kekayaan yang terbatas. ${ }^{1}$

\section{Sebelum}

perkawinan

dilangsungkan calon suami istri masih dapat mengubah perjanjian kawin yang dibuatnya. Akan tetapi perubahan itu harus dilakukan dengan akta notaris. Sedangkan orang yang dahulu ikut serta sebagai pihak dalam mewujudkan perjanjian kawin itu harus dikutsertakan lagi. Bilamana orang-orang itu tidak menyukai, maka tindakan dapat diadakan perubahan.

Perubahan harus mendapatkan pengesahan oleh pengadilan, bertujuan untuk menjamin, agar orang tidak gegabah melakukan perubahan. Pengesahan itu harus ditolak, bila pengesahan itu tidak mempunyai dasar yang wajar atau menimbulkan bahaya bagi pihak ketiga. Dalam pembuatan perjanjian kawin adakalanya pihak ketiga dapat juga ikut serta, sebab pihak ketiga dapat memberikan hadiah-hadiah dalam perkawinan kedua belah pihak itu dengan ketentuan tidak akan jatuh ke dalam kebersamaan harta mereka. ${ }^{2}$

Dalam pasal 29 ayat (1) UndangUndang Nomor 1 Tahun 1974 Tentang Perkawinan menyebutkan, bahwa pada waktu atau sebelum perkawinan dilangsungkan, kedua belah pihak atas persetujuan bersama dapat mengadakan perjanjian tertulis yang disahkan oleh pegawai pencatat perkawinan, setelah mana isinya berlaku juga terhadap pihak ketiga sepanjang pihak ketiga tersangkut.

Pada umumnya atau sebagian besar rakyat Indonesia tidak mengenal perjanjian kawin. Lembaga tersebut diperkenalkan pada waktu itu melalui Kitab Undang-Undang Hukum Perdata, sedangkan mengenai waktu pembuatan perjanjian kawin, Undang-

\footnotetext{
hlm. 58

${ }^{1}$ R. Soetojo Prawirohamidjojo, Op.cit, hlm. 60
}

undang memberikan dua macam waktu, yaitu sebelum atau pada saat perkawinan dilangsungkan. ${ }^{3}$

Dalam Pasal 29 ayat (2) UndangUndang Nomor 1 Tahun 1974 Tentang Perkawinan menyatakan, untuk pengesahannya yang diberi wewenang oleh undang-undang adalah pegawai pencatat perkawinan. Pengesahan hanya diberikan, bila tidak melanggar batas-batas hukum, agama dan kesusilaan. Adapun yang dimaksud tidak melanggar hukum, agama dan kesusilaan adalah :

1. Hukum

Kaedah hukum adalah segala peraturan yang ada yang telah dibuat secara resmi oleh pemegeng kekuasaan, yang sifatnya mengikat setiap orang dan pemberlakuannya merupakan paksaan yang harus ditaati dan apabila telah terjadi pelanggaran akan dikenakan sanksi tertentu.

2. Agama

Kaedah agama ditujukan kepada kehidupan beriman dan terhadap kewajiban manusia kepada tuhan dan dirinya sendiri yang berasal dari ajaran-ajaran kepercayaan atau agama ayang dianut manusia. Kaedah ini bertujuan untuk penyempurnaan manusia oleh karena kaedah ini ditujukan kepada umat manusia dan melarang manusia untuk berbuat jahat. Kaedah ini bukan hanya ditujukan kepada sikap lahir, tetapi juga kepada sifat bathin manusia. Diharapkan dari manusia bahwa sikap bathinnya sesuai dengan agama dan kepercayaan.

3. Kesusilaan

Kaedah kesusilaan berhubungan dengan manusia sebagai individu karena hlm. 61
${ }^{3}$ R. Soetojo Prawirohamidjojo, Op.cit, 
menyangkut kehidupan pribadi manusia. Sebagai pendukung kaedah kesusilaan adalah nurani individu dan bukan manusia sebagai makhluk sosial atau sebagai anggota masyarakat yang terorganisir. Kaedah ini dapat melengkapi ketidakseimbangan hidup pribadi mencegah kegelisahan diri sendiri. Kaedah kesusilaan ini ditujukan kepada umat manusia agar terbentuk kebaikan akhlak pribadi guna penyempurnaan manusia dan melarang manusia untuk berbuat jahat. $^{4}$

Dalam Pasal 29 ayat (3) UndangUndang Nomor 1 Tahun 1974 Tentang Perkawinan menyatakan juga perjanjian kawin tersebut mulai berlaku sejak perkawinan berlangsung, artinya tidak boleh ditentukan waktu lain. Hal ini sama dengan ketentuan Kitab UndangUndang Hukum Perdata. Sebaliknya perjanjian kawin menjadi gugur bila perkawinan itu tidak dilangsungkan.

Dan dalam Pasal 29 ayat (4) Undang-Undang Nomor 1 Tahun 1974 Tentang Perkawinan menyatakan, bahwa selama perkawinan berlangsung perjanjian tersebut tidak dapat diubah, kecuali bila kedua belah pihak ada persetujuan untuk mengubah dan perubahannya tidak merugikan pihak ketiga.

Lahirnya Putusan Mahkamah Kostitusi nomor 69/PUU-XIII/2015 tentunya di dasari oleh adanya hak konstitusional Warga Negara Indonesia yang dirugikan oleh ketentuan bahwa perjanjian kawin hanya dapat dibuat sebelum perkawinan dilangsungkan. Putusan Mahkamah Konstitusi mengubah beberapa ketentuan yang sebelumnya diatur dalam Pasal 29 Undnag-Undang

${ }^{4}$ http://scholar.unand.ac.id/22473/2/BAB\%20I.pdf
Nomor 1 Tahun 1974 Tentang Perkawinan antara lain bahwa perjanjian kawin boleh dibuat sebelum, pada saat dan selama dalam ikatan perkawinan. Ketentuan tersebut mengesampingkan ketentuan yang ada sebelumnya bahwa perjanjian kawin hanya dapat dibuat sebelum perkawinan dilangsungkan.

Ditegaskan pula dalam Putusan Mahkamah Konstitusi tersebut bahwa perjanjian kawin dibuat secara tertulis yang disahkan oleh pegawai pencacat perkawinan atau Notaris. Ketentuan ini mempertegas siapa saja yang berwenang mengesahkan perjanjian kawin tersebut. Sebelumnya hanya disebutkan bahwa perjanjian kawin disahkan oleh pegawai pencatat perkawinan namun sejak berlakunya Putusan Mahkamah Konstitusi tersebut penegesahan perjanjian kawin juga dapat dilakukan dihadapan Notaris.

Dapat dilihat pula bahwa perjanjian kawin tersebut berlaku sejak perkawinan dilangsungkan apabila perjanjian kawin dibuat sebelum perkawinan atau sejak waktu yang ditentukan dalam perjanjian apabila dibuat selama dalam ikatan perkawinan. Dan yang terakhir mengenai Putusan Mahkamah Kostitusi ini adalah kesepakatan kedua belah pihak, selama hal tersebut tidak merugikan pihak ketiga. Sebelum adanya Putusan Mahkamah Konstitusi ini perjanjian kawin hanya dapat diubah saja tetapi tidak dapat dicabut.

Hadirnya Putusan Mahkamah Konstisusi tersebut di satu sisi membawa dampak positif bagi pihakpihak yang sudah terikat dalam perkawinan namun pada saat perkawinan dilaksanakan tidak membuat perjanjian kawin dan kemudian baru menyadari perlunya dibuat perjanjian kawin dalam perjanjian kawin yang dibuat selama perkawinan berlangsung. 
B. Akibat Hukum Perjanjian Kawin Yang Dibuat Setelah Perkawinan Terhadap Pihak Ketiga

Perakawinan merupakan kesepakatan bersama antara suami dan istri untuk hidup bersama, dan tentu saja mengakibatkan hak dan kewajiban bagi kedua belah pihak. Setiap suami mempunyai hak dalam keluarga, begitu juga seorang wanita yang mengikatkan diri menjadi istri dalam suatu perkawinan memiliki hak sebagai istri, yang dimaksud dengan hak tidak lain adalah suatu yang merupakan milik atau dapat dimiliki oleh suami istri yang diperoleh dari hasil perkawinan. Hak ini juga dapat dihapus apabila yang berhak rela haknya tidak dipenuhi atau dibayar oleh pihak lain. Dalam Pasal 30 Undang-Undang Nomor 1 Tahun 1974 Tentang Perkawinan dinyatakan bahwa suami istri memikul kewajiban yang lahir untuk menegakkan rumah tangga yang menjadi sendi dasar dari susunan masyarakat.

Akibat dari perkawinan yang berkaitan dengan harta benda dalam perkawinan diatur dalam Pasal 35 sampai dengan Pasal 37 UndangUndang Nomor 1 Tahun 1974 Tentang Perkawinan, yang intinya menetapkan sebagai berikut $:^{5}$

1. Harta benda yang diperoleh selama perkawinan menjadi milik bersama, sedangkan :

a) Harta bawaan dari masingmasing suami istri.

b) Harta benda yang diperoleh masing-masing suami istri sebagai hadiah.

c) Warisan.

Adalah dibawah pengusaan masing-masing, sepanjang tidak ditentukan

${ }^{5}$ Mulyadi, Hukum Perkawinan Indonesia, Fakultas Hukum Universitas Diponegoro,

Semarang, 1992, hlm. 55 lain oleh suami istri. Apabila kemudian ditentukan oleh suami istri, maka harta bawaan suami istri menjadi harta bersama. Untuk menentukan agar harta bawaan suami istri atau yang diperoleh selama perkawinan menjadi atau tidak menjadi harta bersama, maka suami istri tersebut harus membuat perjanjian kawin terlebih dahulu.

Perjanjian kawin harus dibuat secara tertulis dan disahkan oleh Pegawai Pencatat Perkawinan sebelum atau pada saat perkawinan dilangsungkan. Perjanjian kawin adalah perjanjian yang dibuat calon suami istri untuk mengatur akibat-akibat

perkawinannya terhadap harta kekayaan mereka.

Perjanjian kawin diatur di dalam Pasal 29 UndangUndang Nomor 1 Tahun 1974 Tentang Perkawinan, yang menetapkan :

a. Pada waktu atau sebelum perkawinan dilangsungkan, kedua pihak atas persetujuan bersama dapat mengadakan Perjanjian Kawin yang disahkan oleh Pegawai Pencatat Perkawinan, dimana isinya berlaku juga terhadap pihak ketiga, sepanjang pihak ketiga tersangkut.

b. Perjanjian tersebut tidak dapat disahkan, jika melanggar batasbatas hukum agama dan kesusilaan. 
c. Perjanjian tersebut berlaku sejak perkawinan dilangsungkan.

d. Selama perkawinan berlangsung perjanjian tersebut tidak dapat diubah, kecuali bila dari kedua belah pihak ada persetujuan untuk merubah asalkan perubahan mana tidak merugikan pihak ketiga.

2. Mengenai harta bersama, suami istri dapat bertindak atas persetujuan kedua belah pihak. Sedangkan mengenai harta bawaan masing-masing, suami istri mempunyai hak sepenuhnya untuk melakukan perbuatan hukum mengenai harta bendanya. Adapun hak suami dan istri untuk mempergunakan atau memakai harta bersama dengan persetujuan kedua belah pihak secara timbal balik atau sewajarnya, mengingkat hak dan kedudukan suami maupun istri dalam kehidupan rumah tangga dan bermasyarakat, dimana masing-masing pihak berhak melakukan perbuatan hukum.

3. Bila perkawinan putus karena perceraian, maka harta bersama diatur menurut hukumnya masing-masing. Menurut penjelasan Pasal 37 Undang-Undang Nomor 1 Tahun $1974 \quad$ Tentang Perjanjian Perkawinan, yaitu hukum agama (kaedah agama), hukum adat dan hukum-hukum lainnya.

$\begin{array}{rcr}\text { Sesuai } & \text { dengan } & \text { Putusan } \\ \text { Mahkamah } & \text { Konstitusi } & \text { Nomor }\end{array}$

69/PUU-XIII/2015 yang menyebutkan bahwa perjanjian kawin harus dibuat dengan akta Notaris. Yang diatur pula dalam Pasal 147 Kitab UndangUndang Hukum Perdata. Perjanjian kawin tersebut wajib didaftarkan ke Kantor Catatan Sipil, hal tersebut diatur dalam Pasal 29 ayat (1) Undang-Undang Perkawinan jo Pasal 152 Kitab Undang-Undang Hukum Perdata.

Yang mana tujuan didaftarkannya perjanjian kawin tersebut adalah untuk menunjukan kepada pihak ketiga bahwa adanya perjanjian kawin terhadap perkawinan tersebut yang juga berlaku terhadapnya (pihak ketiga) yang terkait terhitung sejak didaftarkannya perjanjian kawin tersebut.

Sebagaimana akibat hukum dari perkawinan yang sah, maka perjanjian perkawinan yang dibuat setelah perkawinan juga sudah pasti akan menimbulkan akibat hukum baik terhadap pihak yang membuatnya, terhadap harta benda, maupun terhadap pihak ketiga yang terkait :

1. Akibat hukum terhadap pihak yang membuatnya

Pembuatan perjanjian perkawinan setelah perkawinan adalah merupakan persetujuan dan kesepakatan dari kedua belah pihak suami istri untuk membuat perjanjian perkawinan setelah perkawinan ini berlaku dan mengikat bagi kedua belah pihak yang membuat perjanjian tersebut. Hal ini sesuai dengan ketentuan dalam Pasal 1338 KHUPerdata yang berbunya : "semua perjanjian yang dibuat secara sah berlaku sebagai undang-undang bagi mereka yang membuatnya."

Perjanjian kawin setelah perkawinan ini terbentuk karena adanya persetujuan dan 
tercapainya kata sepakat antara para pihak yang membuatnya. Yang dalam hal ini adalah para pemohon atau suami istri, sehingga dengan sendirinya perjanjian perkawinan ini juga mengikat secara hukum bagi para pihak yang membuatnya saat keduanya sepakat tentang perjanjian perkawinan tersebut untuk memenuhi kesepakatan yang terdapat dalam perjanjian perkawinan tersebut.

2. Akibat hukum terhadap harta benda kekayaan

Setelah adanya perjanjian perkawinan maka harta benda masing-masing pihak suami istri akan menjadi semakin kuat pula secara hukum. Masing-masing pihak suami maupun istri harus mematuhi segala isi perjanjian perkawinan tersebut sebab segala hal yang menyangkut pemisahan harta sudah jelas dipisahkan, juga terhadap harta-harta lain yang kemudian hari timbul setelah tanggal perjanjian tersebut tetap terpisah satu dengan yang lainnya, sehingga tidak ada lagi berstatus harta bersama. Sebagaimana yang dinyatakan dalam Pasal 164 KUHPerdata bahwa apabila dijanjikan suatu persatuan hasil dari pedapatan, mata tidak akan terjadi persatuan harta kekayaan secara bulat dan persatuan untung rugi.

Demikian juga halnya dengan hutang piutang yang ditimbulkan akibat perbuatan hukum dari pasangan hidupnya yang dilakukan setelah perjanjian perkawinan menjadi tanggung jawab dari pasangan hidupnya. Sehingga adanya perjanjian perkawinan ini dapat melindungi secara hukum harta benda kekayaan yang dimiliki oleh masing-masing pihak suami istri.
3. Akibat hukum terhadap pihak ketiga

Berlakunya perjanjian perkawinan juga akan berakibat hukum terhadap pihak ketiga yang berkaitan dengannya, sesuai dengan ketentuan Pasal 147 juncto Pasal 157 KUHPerdata bahwa sejak perkawinan dilangsungkan perjanjian perkawinan hanya berlaku bagi para pihak yang membuatnya yaitu pasangan suami istri, sedangkan perjanjian perkawinan baru berlaku terhadap pihak ketinga sejak didaftarkan di Pegawai Pencatat Perkawinan atau Kantor Catatan Sipil.

Pembuatan

perjanjian perkawinan yang hubungannya terhadap pihak ketiga akan berlaku sejak tanggal didaftarkannya ke Kantor Catata Sipil atau Pegawai Pencatat Perkawinan. Sehingga pihak ketiga dalam hal ini tidak dirugikan jika terjadi sesuatu dikemudian hari, karena sudah ada kesepakatan pemisahan harta sebelumnya. Namun jika pihak ketiga (kreditur) bisa membuktikan bahwa yang dijadikan jaminan hutang atau diperjanjikan sebagai jaminan dalam bentuk apapun diperoleh sebelum didaftarkannya ke pegawai pencatat perkawinan maka pihak ketiga dapat menuntut pelunasannya terhadap harta bersama suami istri. Sedangkan utang yang dibuat oleh salah satu pihak suami atau istri setelah dicatat oleh pegawai pencatat perkawinan tersebut maka pihak ketiga dapat ditagih pelunasannya terhadap pihak suami atau pihak istri yang berhutang. ${ }^{6}$ 
Dari penjelasan diatas, diketahui bahwa akibat dari perjanjian kawin yang dibuat setelah perkawinan atau dalam ikatan perkawinan mempunyai akibat yang sangat besar terhadap harta benda kekayaan dari masingmasing suami istri. Yang dapat mengubah status hukum harta benda yang diperoleh didalam perkawinan tersebut, yang pada mulanya sebelum adanya perjanjian kawin harta benda tersebut adalah berstatus harta bersama dalam perkawinan, namun adanya perjanjian kawin tersebut terjadi perubahan menjadi harta pribadi dari masing-masing suami istri. Sehingga dapat membuat kerugian bagi pihak ketiga yang terakait. Dalam hal ini untuk melindungi kepentingan pihak ketiga tersebut sudah seharusnya terdapat tata cara yang harus ditempuh agar pihak ketiga tidak dirugikan akibat adanya perjanjian kawin tersebut.

Sebagaimana yang telah dijelaskan dalam Putusan Mahkamah Konstitusi bahwa perjanjian kawin yang dibuat harus didaftarkan ke Kantor Catatan Sipil sesuai dengan penjelasan diatas. Dengan tujuan agar pihak ketiga mengetahui adanya perjanjian kawin yang juga berlaku terhadapnya. Namun haruslah dipahami apabila perjanjian kawin yang dibuat setelah perkawinan tersebut tidak berhubungan dengan pihak ketiga maka berlakunya perjanjian kawin tersebut adalah terhitung pada saat perkawinan dilangsungkan apabila tidak ditentukan lain. Dan dalam hubungannya dengan pihak ketiga perjanjian kawin tersebut berlaku sejak didaftarkannya ke Kantor Catatan Sipil.
Apabila perjanjian kawin tersebut dibuat sesudah adanya perjanjian dengan pihak ketiga, maka harus pula memperhatikan hak yang dimiliki pihak ketiga. Dan apabila pihak ketiga (kreditur) merasa dirugikan adanya perjanjian kawin yang dibuat setelah perkawinan tersebut, kreditur dapat melakukan gugatan atas dasar Asas Actio Pauliana. Meskipun perjanjian kawin dibuat dan berlaku bagi pihakpihak didalamnya, namun dalam hal ini kreditur merasa dirugikan atas dibuatnya perjanjian kawin dalam waktu perkawinan.

Actio Pauliana yang diatur dalam Pasal 1341 Kitab Undang-Undang Hukum Perdata merupakan suatu upaya hukum yang dapat dilakukan oleh pihak ketiga yang merasa dirugikan atas suatu perjanjian yang dibuat oleh pihak-pihak lain, untuk minta dibatalkan ke Pengadilan. Apabila gugat yang diajukan pihak ketiga tersebut dikabulkan oleh hakim, maka perjanjian kawin yang bersangkutan dinyatakan batal. ${ }^{7}$ Yang mana kreditur dapat melakukan tuntuan pembatalan pada saat debitur melakukan tindakan yang merugikan kreditur dengan hak kreditur menjadi Asas Actio Pauliana.

Dengan adanya ketentuan tersebut dapat membatasi tindakan hukum dari debitur. Meskipun seorang debitur bebas untuk melakukan tindakan apa saja atas hak kepemilikan atas kebendaan miliknya namun dalam hal ini Kitab Undang-Undang Hukum Perdata juga membatasi tindakan dari debitur apabila tindakan tersebut akan merugikan kreditur nantinya. setelah-perkawinan-ditinjau-dari-kitab-undangundang-hukum-perdata

\footnotetext{
${ }^{7}$ Moch. Isnaeni, Pijar Pendar Hukum Perdata, Revka Petra Media, Surabaya, 2016, hlm. 152
} 


\section{PENUTUP}

\section{A. Kesimpulan}

1. Perjanjian kawin yang dibuat setelah perkawinan dilangsungkan adalah untuk mengatur akibat perkawinan terhadap harta kekayaan perkawinan. Dengan perjanjian kawin yang dibuat setelah perkawinan tersebut ada perubahan status harta kekayaan perkawinan, yang semula merupakan harta bersama, karena terjadi persatuan harta, menjadi harta pribadi sesuai kepemilikannya masing-masing, karena telah diadakan pemisahan harta berdasarkan perjanjian kawin tersebut. Perjanjian kawin yang dibuat setelah perkawinan berlangsung adalah sah menurut hukum yang berlaku di Indonesia, karena lahirnya Putusan Mahkmah Konstitusi Nomor 69/PUU-XIII/2015.

2. Lahirnya Putusan Mahkamah Konstitusi Nomor 69/PUUXIII/2015, berlakunya pula perjanjian kawin yang dibuat setelah perkawinan, dalam hubungan antara pihak istri yang membuatnya apabila tidak diperjanjikan lain terhitung sejak perkawinan, namun berlakunya bagi pihak ketiga adalah terhitung sejak didaftarkan dan tidak berlaku surut. Pihak ketiga yang dirugikan akibat adanya perjanjian kawin tersebut dapat mengajukan gugatan pembatalan atas dasar asas Actio Paulina.

\section{B. Saran}

1. Melihat pesatnya perkembangan jaman modern sekarang ini dan munculnya masalah-masalah dalam perkawinan, terutama dalam hal harta kekayaan perkawinan ataupun harta milik pribadi sebelum perkawinan. Perlu diadakan sosialisasi pembuatan perjanjian kawin secara otentik, yaitu sosialisasi bahwa perjanjian kawin harus dibuat secara noatriil. Pembuatan akta kepada Notaris juga harus disosialisasikan, karena dalam membuat perjanjian kawin dibutuhkan suatu keahlian khusus, yaitu orang yang harus paham benar akan hukum dan dapat merumuskan akta dengan memenuhi syarat-syarat dan hatihati, karena perubahan perjanjian perkawinan setelah perkawinan bukanlah hal yang mudah untuk dilakukan.

2. Dengan adanya Putusan Mahkamah Konstitusi Nomor 69/PUU-XIII/2015, yang mengubah ketentuan Pasal 29 Undang-Undang Nomor 1 Tahun 1974 Tentang Perkawinan. Yang mana perjanjian kawin dapat dibuat oleh suami istri dalam keadaan sebelum pernikahan, pada saat pernikahan, dan dalam ikatan pernikahan, dapat membuat peluang kerugian pihak ketiga, untuk itu Notaris harus teliti dalam penerapan obyek perjanjian kawin setelah perkawinan.

\section{DAFTAR PUSTAKA}

\section{A. Artikel}

http://scholar.unand.ac.id/22473/2/BAB \%20I.pdf

https://media.neliti.com/media/publicati ons/13982-ID-perjanjianperkawinan-yang-dibuat-setelahperkawinan-ditinjau-dari-kitabundang-undang-hukum-perdata

\section{B. Literatur}

Peter Mahmud Marzuki, Penelitian Hukum, Jakarta : Prenamedia Group, 2005 
R. Soetojo Prawirohamidjojo, Pluralisme Dalam Perundang-

Undangan Perkawinan di Indonesia, Airlangga University Press, Surabaya, 2012

Mulyadi, Hukum Perkawinan Indonesia, Fakultas Hukum Universitas Diponegoro, Semarang, 1992.

Moch. Isnaeni, Pijar Pendar Hukum Perdata, Revka Petra Media, Surabaya, 2016

\section{Perundang-Undangan}

Undang-Undang Nomor 1 Tahun 1974 Tentang Perkawinan dan Kompilasi Hukum Islam,

Bandung : Citra Umbara, 2012

Kitab Undang-Undang Hukum

Perdata, Perdata (Burgerlijk

Wetboek). Diterjemahkan oleh R.

Subekti. Jakarta : Balai Pustaka, 2004

Undang-Undang Nomor 30 Tahun 2014 Tentang Administrasi Pemerintahan

Peraturan Pemerintah Nomor 9

Tahun 1975 Tentang Pelaksanaan

Undang-Undang Perkawinan

Putusan Mahkamah Konstitusi Nomor 69/PUU-XIII/2015 